\title{
Sulfur and Nitrogen Availability Interact to Affect the Flavor Biosynthetic Pathway in Onion
}

\author{
Timothy W. Coolong1 and William M. Randle ${ }^{2}$ \\ Department of Horticulture, University of Georgia, Athens, GA 30602
}

\begin{abstract}
AdDitional InDEX wORDs. Allium cepa, methyl cysteine sulfoxide, 1-propenyl cysteine sulfoxide, propyl cysteine sulfoxide
Abstract. To determine the extent to which sulfur $(S)$ and nitrogen $(N)$ fertility interact to influence the flavor biosynthetic pathway in onion (Allium cepa L.), 'Granex 33' onions were grown in hydroponic solution culture with varying levels of $S$ and $N$ availability. Plants were grown at 5,45 , or $125 \mathrm{mg} \cdot \mathrm{L}^{-1}$ sulfate $\left(\mathrm{SO}_{4}^{2-}\right)$, and $10,50,90$, or $130 \mathrm{mg} \cdot \mathrm{L}^{-1}$ $\mathrm{N}$, in a factorial combination. Total bulb $\mathrm{S}$, total and individual flavor precursors and their peptide intermediates in intact onion tissue were measured. To measure the effect of $S$ and $N$ on alliinase activity, flavor precursors were also measured in onion macerates. Sulfur and $\mathbf{N}$ availability in the hydroponics solution interacted to influence all flavor compounds except $S$-methyl-L-cysteine sulfoxide. Levels of $S$-methyl-L-cysteine sulfoxide were influenced by $N$ and $S$ levels in the solutions; however, no interaction was present. At the lowest $\mathrm{SO}_{4}{ }^{2-}$ or $\mathrm{N}$ levels, most precursors and peptides measured were present in very low concentrations. When $\mathrm{SO}_{4}{ }^{2-}$ or $\mathrm{N}$ availability was adequate, differences among flavor compounds were small. Results indicated that $\mathrm{S}$ fertility had a greater influence on trans-S-1-propenyl-L-cysteine sulfoxide (1-PRENCSO) accumulation, while $\mathrm{N}$ availability had a greater influence on S-methyl-L-cysteine sulfoxide levels. Flavor precursors remaining in the onion macerates revealed that the percentage of intact precursors hydrolyzed by alliinase were not significantly influenced by either $\mathrm{SO}_{4}{ }^{2-}$ or $\mathrm{N}$ levels in the solutions, except for 1-PRENCSO, which was affected by $\mathbf{N}$ levels. Nitrogen and $\mathrm{S}$ fertility interacted to influence the flavor biosynthetic pathway and may need to be considered together when manipulating onion flavor compounds.
\end{abstract}

Onions (Allium cepa L.), have been cultivated since antiquity primarily for their flavoring properties. Onion flavor is dominated by the presence of organosulfur compounds, in particular the $S$ alk(en)yl-L-cysteine-sulfoxides (ACSO). During consumption onion vacuoles lyse allowing the enzyme alliinase to hydrolyze the individual ACSOs in the bulb, giving rise to the compounds responsible for onion's characteristic flavor and aroma. As such, onions accumulate large quantities of sulfur (S). Randle (1992) reported bulb $\mathrm{S}$ concentrations in excess of $1 \%$ on a dry weight basis in plants grown with high $\mathrm{S}$ fertility. Much of the $\mathrm{S}$ taken up by onions is partitioned into organosulfur compounds as part of the flavor biosynthetic pathway. Randle et al. (1995) reported that up to $95 \%$ of the organically bound $\mathrm{S}$ in onion bulbs grown with low $\mathrm{S}$ fertility could be accounted for in compounds from the flavor biosynthetic pathway.

Sulfur enters the plant actively as sulfate $\left(\mathrm{SO}_{4}{ }^{2-}\right)$. Sulfate is transported to the leaves, where it can be stored in the vacuole or be reduced to sulfide and assimilated into cysteine in the chloroplast (Hell, 1997). Cysteine is quickly incorporated into proteins or used in the synthesis of methionine and glutathione (Leustek et al., 2000). In onion, cysteine and glutathione serve as precursors to several gamma-glutamyl peptides $(\gamma \mathrm{GP})$, which are used in the flavor biosynthetic pathway (Randle and Lancaster, 2002).

Because the ACSOs and their breakdown products are organosulfur compounds, S fertility has been thoroughly investigated as a means of altering onion flavor. Onion pungency increased in response to enhanced S fertility (Freeman and Mossadeghi, 1970; Hamilton et al., 1997; Randle 1992; Randle and Bussard, 1993). Changes in $\mathrm{S}$ fertility also resulted in alterations in the concentration and composition of the ACSOs in onion, which ultimately could influence flavor quality in the bulb (Randle et

Received for publication 30 Dec. 2002. Accepted for publication 24 Apr. 2003. This paper is part of a thesis by T.W. Coolong. Mention of a proprietary product or vendors by the authors does not imply its approval to the exclusion of other products or vendors that may also be suitable.

${ }^{1}$ Graduate assistant.

${ }^{2}$ Professor of horticulture. al., 1995). As a result it is generally accepted that $\mathrm{S}$ fertility is a primary factor by which one can greatly alter onion flavor. The influence of most other mineral nutrients on onion flavor are less understood.

Most investigations on the effects of $\mathrm{N}$ fertility and onion have focused on developmental and yield aspects (Brewster and Butler, 1989; Brown et al., 1988; Drost et al., 2002; Hussaini et al., 2000). However, Randle (2000) reported that very high levels of nitrogen $(\mathrm{N})$ could influence onion pungency as well as the composition of ACSOs in the bulb. Additionally, $\mathrm{N}$ form in a hydroponic solution was shown to affect onion pungency (Gamiely et al., 1991). Because high-N fertility has affected onion flavor, further inquiries using lower $\mathrm{N}$ levels are warranted.

Several investigations have shown a relationship between nitrate $\left(\mathrm{NO}_{3}{ }^{-}\right)$and $\mathrm{SO}_{4}{ }^{2-}$ reduction in plants. A $50 \%$ to $70 \%$ decrease in adenosine 5' - phosphosulfate reductase (APR), a key enzyme in $\mathrm{SO}_{4}{ }^{2-}$ assimilation, in response to the absence of $\mathrm{N}$ fertility in Arabidopsis thaliana was reported (Koprivova et al. 2000). Decreases in APR as well as adenosine triphosphate sulfurylase were also observed in Lemna minor when plants were exposed to decreasing $\mathrm{NO}_{3}{ }^{-}$levels (Brunold and Suter, 1984). Restricted $\mathrm{NO}_{3}{ }^{-}$fertility repressed another enzyme, ferredoxin-sulfite reductase, in the $\mathrm{SO}_{4}{ }^{2-}$ reduction pathway in leek (A. tuberosum) (Takahashi et al., 1996). Sulfur and $N$ fertility interacted to influence $S$ values in Brassica napus, a high-S accumulating plant (Pinkerton, 1998). Additionally, $\mathrm{S}$ deprivation reduced $\mathrm{NO}_{3}-$ uptake in curly kale $(B$. oleracea L.) (Stuiver et al., 1997).

Our purpose was to investigate the interaction of varying levels of $\mathrm{N}$ and $\mathrm{S}$ availability on the flavor biosynthetic pathway in onion. Previous investigations reported on either $\mathrm{N}$ or $\mathrm{S}$ alone, with no chance to observe possible interactions.

\section{Materials and Methods}

Plant culture. On 25 Jan. 2002, 'Granex 33' onions (Asgrow Seeds, Kalamazoo, Mich.) were seeded into sheets of $16.4 \mathrm{~cm}^{3}$ rock-wool cubes (Grodan, Hedenhusene, Denmark). Seedlings 
were fertilized twice weekly with a full strength Hoagland's \#2 nutrient solution and watered as needed (Hoagland and Arnon, 1950). Seedlings were greenhouse grown at day/night setpoints of $25 / 18{ }^{\circ} \mathrm{C}$ under natural photoperiods $\left(\approx 34^{\circ} \mathrm{N}\right.$ latitude) for 5 weeks. Radiant flux as measured at noon on a clear sunny day was $1230 \mu \mathrm{mol} \cdot \mathrm{m}^{-2} \cdot \mathrm{s}^{-1}$. Seedlings received two applications of metalaxyl (Ridomil; Syngenta, Greensboro, N.C.) at 2 and 4 weeks of age. On 3 Mar. 2002 plants were transferred to 37.9-L plastic containers (Rubbermaid, Inc., Wooster, Ohio). Ten plants were placed in $2.54 \mathrm{~cm}$ diameter holes spaced $10 \times 16 \mathrm{~cm}$ on the container lids. Each container was brought to $28 \mathrm{~L}$ with deionized water and nutrient salts were added. The study was a three $\times$ four factorial design, with three $\mathrm{SO}_{4}{ }^{2-}$ treatment levels and four $\mathrm{N}$ treatment levels. The experiment was completely randomized with 12 total treatment levels, each having four replications with ten plants per replication. The $\mathrm{S}$ levels consisted of 5, 45, and $125 \mathrm{mg} \cdot \mathrm{L}^{-1} \mathrm{SO}_{4}{ }^{2-}$, that were achieved by the addition of 12.9 , 115.8 , and $321.3 \mathrm{mg} \cdot \mathrm{L}^{-1} \mathrm{MgSO}_{4} \cdot 7 \mathrm{H}_{2} \mathrm{O}$, respectively. The levels of $\mathrm{SO}_{4}^{2-}$ were so chosen because previous research has shown that onion flavor is most responsive to $\mathrm{SO}_{4}{ }^{2-}$ over a similar range (Freeman and Mossadeghi, 1970; Randle et al., 1995). Magnesium concentrations were balanced through the addition of 253.5 and $168.4 \mathrm{mg} \cdot \mathrm{L}^{-1} \mathrm{MgCl}_{2} \cdot 6 \mathrm{H}_{2} \mathrm{O}$ to the 5 and $45 \mathrm{mg} \cdot \mathrm{L}^{-1}$ $\mathrm{SO}_{4}{ }^{2-}$ treatments, respectively. Chloride concentrations were not balanced, and ranged between 132 and $219 \mathrm{mg} \cdot \mathrm{L}^{-1}$ in this study, which are well within concentrations used in previous studies (Randle and Bussard, 1993; Randle et al., 1995). The N treatment levels consisted of $10,50,90$, and $130 \mathrm{mg} \cdot \mathrm{L}^{-1} \mathrm{~N}$, which were achieved through the addition of $28.5,142.7,256.5$, and $371 \mathrm{mg} \cdot \mathrm{L}^{-1} \mathrm{NH}_{4} \mathrm{NO}_{3}$, respectively. The $\mathrm{N}$ levels used were based on previous research indicating that onion flavor responded to a wide range of $\mathrm{N}$ concentrations (Coolong, 2003). All solutions contained $174.2 \mathrm{mg} \cdot \mathrm{L}^{-1} \mathrm{~K}_{2} \mathrm{HPO}_{4}, 95 \mathrm{mg} \cdot \mathrm{L}^{-1} \mathrm{KCl}, 138 \mathrm{mg} \cdot \mathrm{L}^{-1}$ $\mathrm{CaCl}_{2}, 10 \mathrm{mg} \cdot \mathrm{L}^{-1}$ iron chelate (Sequestrene 330), $2.86 \mathrm{mg} \cdot \mathrm{L}^{-1}$ $\mathrm{H}_{3} \mathrm{BO}_{3}, 1.81 \mathrm{mg} \cdot \mathrm{L}^{-1} \mathrm{MnCl}_{2} \cdot 4 \mathrm{H}_{2} \mathrm{O}, 0.22 \mathrm{mg} \cdot \mathrm{L}^{-1} \mathrm{ZnSO}_{4} \cdot 7 \mathrm{H}_{2} \mathrm{O}, 0.08$ $\mathrm{mg} \cdot \mathrm{L}^{-1} \mathrm{CuSO}_{4} \cdot 7 \mathrm{H}_{2} \mathrm{O}$, and $0.04 \mathrm{mg} \cdot \mathrm{L}^{-1} \mathrm{Na}_{2} \mathrm{MoO}_{4} \cdot 2 \mathrm{H}_{2} \mathrm{O}$. Nutrient solutions were brought to volume daily with deionized water and were completely replaced every two weeks. The average $\mathrm{pH}$ of initial solutions were 7.3 , which fell to 6.3 over the 2 -week period. Electrical conductivity (EC) of the nutrient solutions was measured at the beginning and end of each 2-week period (model 09-326; Fisher Scientific, Pittsburgh, Pa.). Average EC of the initial solutions ranged from $\approx 1100$ to $1800 \mu \mathrm{S} \cdot \mathrm{cm}^{3}$ and fell to between 1000 to $1600 \mu \mathrm{S} \cdot \mathrm{cm}^{-3}$ early in the experiment. Average EC measured near the end of the experiment fell to between 600 to $1200 \mu \mathrm{S} \cdot \mathrm{cm}^{-3}$ over the 2 -week period. Solution aeration was provided with a single $14.4 \mathrm{~cm}$ aquarium airstone per tub. Foliage was supported at a height of $\approx 25 \mathrm{~cm}$ above the tub lid with welded wire mesh.

Plants were greenhouse grown to maturity at day/night set points of $25 / 18{ }^{\circ} \mathrm{C}$ under natural photoperiods and light intensities. Plants were considered mature when at least $50 \%$ of the plants in a given treatment had soft pseudostems. Plants were harvested between 15 and 23 June 2002. Plants receiving low $\mathrm{S}$ or $\mathrm{N}$ treatments matured first, while those receiving high $\mathrm{S}$ or $\mathrm{N}$ matured last. At harvest, roots and foliage were removed and average bulb fresh weights were obtained. Bulbs were then placed in mesh bags and cured at ambient greenhouse temperatures for 1 week. The eight most uniform bulbs were selected from each replication for analysis.

Analyses were performed on the combined tissue from each eight-bulb replication. Tissue for the analyses was obtained by cutting three 5-mm-thick longitudinal wedges from each bulb. One wedge group was used to measure total $\mathrm{S}$, while the second wedge group was used to measure the intact ACSOs and $\gamma$ GPs. A third wedge group was used to measure flavor precursors in the onion macerate.

Total Bulbs. Bulb tissue was dried at $65^{\circ} \mathrm{C}$ in a forced air oven (Linberg Blue, Asheville, N.C.) for 5 d. Dried tissue was then ground through a $0.5 \mathrm{~mm}$ screen with a Cyclotec Mill (model 1093; Tector, Hoganas, Sweden). Total bulb S was determined using $0.25 \mathrm{~g}$ of tissue on a Leco $232 \mathrm{~S}$ determinator (Leco Corp., St. Joseph, Minn.). Samples received $0.1 \mathrm{~g}$ of vanadium pentoxide accelerant before analysis (Leco Corp.). Total bulb S was determined by averaging the results from three subsamples from each treatment level and replication. Calibration and S quantification were done using certified standard reference materials (Rice Flour; Leco Corp.).

ACSOS AND THEIR PEPTIDE INTERMEDIATES. The ACSO and $\gamma \mathrm{GP}$ contents from intact bulb tissue were determined according to Randle (2000). The tissue wedges from each eight bulb replication were weighed and the ACSOs and $\gamma$ GPs were extracted twice (using $5 \mathrm{~mL} \cdot \mathrm{g}^{-1}$ fresh weight) in 12 methanol (MEOH): 3 water and once in 12 ethanol (ETOH): 3 water over a $3 \mathrm{~d}$ period. Extracts were then combined into one solution from which 15 $\mathrm{mL}$ was analyzed. Gamma-L-glutamyl-L-glutamic acid (Sigma, St. Louis, Mo.) and ( \pm )-S-1-butyl-L-cysteine sulfoxide, synthesized according to the method of Lancaster and Kelly (1983) and Armstrong and Lewis (1951), were used as internal standards in concentrations of 0.2 and $1.0 \mathrm{mg} \cdot \mathrm{g}^{-1} \mathrm{FW}$, respectively. Standards were added to $15 \mathrm{~mL}$ of the extract solutions, which were then dried using forced air (Evap-o-Rac; Cole Parmer, Vernon Hills, Ill.). The ACSOs measured were: $S$-methyl-L-cysteine sulfoxide (MCSO), trans-S-1-propenyl-L- cysteine sulfoxide (1-PRENCSO), and $S$ propyl-L- cysteine sulfoxide (PCSO). The two $\gamma \mathrm{GPs}$ measured were 2-carboxypropyl glutathione (2-Carb) and gamma-glutamyl propenyl cysteine sulfoxide ( $\gamma$ GPECSO).

ACSOs remaining in the onion macerate were extracted using the method of Lancaster et al. (1998). After an incubation period of $10 \mathrm{~min}$ at room temperature $\left(25^{\circ} \mathrm{C}\right)$, a 0.5 -mL aliquot of onion juice macerate was placed in a $20 \mathrm{~mL}$ scintillation vial to which $10 \mathrm{~mL}$ of $12 \mathrm{MEOH} \mathrm{:} 3$ water was added. Internal standards were added as described above and the entire solution was dried using forced air.

The dried ACSO samples were redissolved in $1 \mathrm{~mL}$ of $18 \mathrm{M} \Omega$ water. A $0.75 \mathrm{~mL}$ aliquot of each solution was then subjected to ion exchange chromatography using a $10 \times 40 \mathrm{~mm}$ column (BioRad, Hercules, Calif.) with $3 \mathrm{~mL}$ of Dowex $1 \times 8$ resin (200 to 400 mesh; Bio-Rad). The ACSOs were separated from the $\gamma$ GPs using four successive concentrations of glacial acetic acid $(0.1$, $0.2,2$ and $5 \mathrm{~m}$ ). The ACSOs and $\gamma \mathrm{GPs}$ were contained in the 0.1 and $2 \mathrm{M}$ fractions while the 0.2 and $5 \mathrm{~m}$ fractions were discarded. The collected fractions were dried under forced air.

Dried sample fractions were redissolved in $1.0 \mathrm{~mL}$ of $18 \mathrm{M} \Omega$ water, from which $100 \mu \mathrm{L}$ was pipetted into a $1.5-\mathrm{mL}$ microcentrifuge vial and dried in vacuo using a Labconco Centrivap Concentrator (Labconco, Kansas City, Mo.). Upon dryness, $250 \mu \mathrm{L}$ of 1 ETOH: 1 Triethylamine (TEA): 1 HPLC water was added to each vial and dried again. Samples were then derivitized by adding 7 ETOH: 1 TEA: 1 phenylisothiocyante : $118 \mathrm{M} \Omega$ water. Vials were immediately flushed with nitrogen gas, capped, and stored at room temperature for $18 \mathrm{~min}$. Vials were then uncapped and dried. Dry samples were redissolved in $1 \mathrm{~mL}$ of 7 water : 2 acetonitrile and transferred to $2.0-\mathrm{mL}$ borosilicate vials for HPLC analysis. 
Table 1. The effects of solution sulfate $\left(\mathrm{SO}_{4}{ }^{2-}\right)$ and nitrogen $(\mathrm{N})$ availability levels on the marginal means and standard errors for bulb fresh weight (FW) and total bulb sulfur (TS) in hydroponically grown 'Granex 33' onions.

\begin{tabular}{lcc}
\hline Solution & $\begin{array}{c}\mathrm{FW} \\
(\mathrm{g} / \mathrm{bulb})\end{array}$ & $\begin{array}{c}\mathrm{TS} \\
(\%)\end{array}$ \\
\hline $\mathrm{SO}_{4}{ }^{2-}\left(\mathrm{mg} \cdot \mathrm{L}^{-1}\right)$ & $118 \pm 7$ & \\
5 & $165 \pm 12$ & $0.160 \pm 0.006$ \\
45 & $170 \pm 12$ & $0.358 \pm 0.026$ \\
125 & $* * *$ & $0.376 \pm 0.028$ \\
& & $* * *$ \\
$\mathrm{~N}\left(\mathrm{mg} \cdot \mathrm{L}^{-1}\right)$ & $97 \pm 2$ & $0.194 \pm 0.006$ \\
10 & $173 \pm 13$ & $0.307 \pm 0.035$ \\
50 & $172 \pm 14$ & $0.335 \pm 0.038$ \\
90 & $166 \pm 6$ & $0.375 \pm 0.046$ \\
130 & $* * *$ & $* * *$ \\
\hline
\end{tabular}
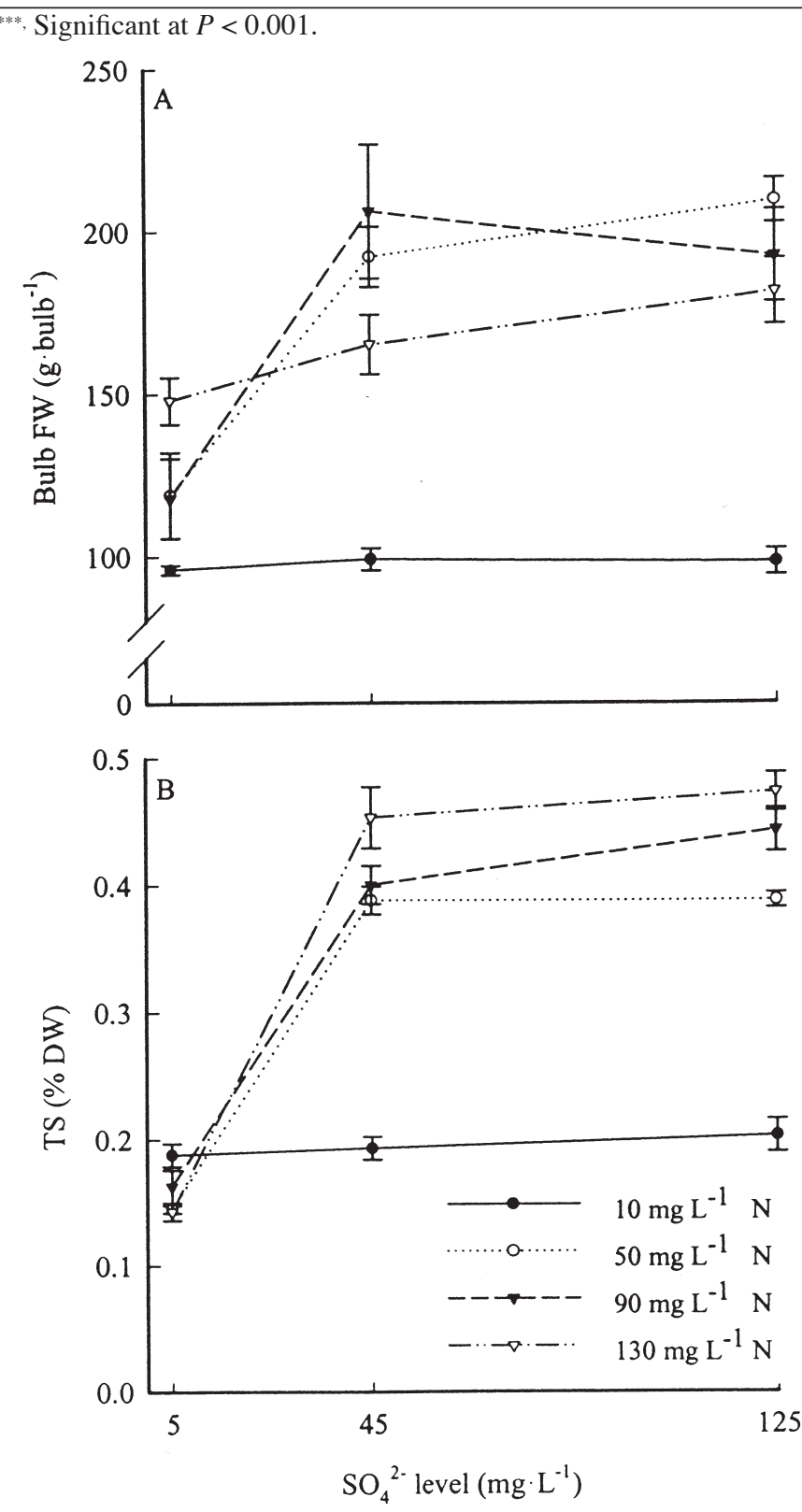

Fig. 1. The effects of solution sulfate $\left(\mathrm{SO}_{4}{ }^{2-}\right)$ and nitrogen $(\mathrm{N})$ availability levels on the average bulb fresh weight (FW) (A) and total bulb sulfur (TS) (B) in hydroponically grown 'Granex 33' onions.
Samples were analyzed on a Waters 2690 Separations Module (Waters Corp.) equipped with an autosamper and coupled to a Waters 996 photodiode array detector (Waters Corp.). Fifty microliters of sample were injected into a $250 \times 4.6 \mathrm{~mm}, 5 \mu \mathrm{m}$ column (Spheri- 5 RP-18; Applied Biosystems, Foster City, Calif.) mated to a $15 \times 3.2 \mathrm{~mm}, 7 \mu \mathrm{m}$ guard column (RP-18 Newgard; Applied Biosystems) for separation. Column temperature was maintained at $30{ }^{\circ} \mathrm{C}$. Eluents were A) aqueous acetonitrile (60\%), B) $0.14 \mathrm{M}$ sodium acetate with $0.05 \%$ TEA buffered to a $\mathrm{pH}$ of $6.35 \mathrm{using}$ glacial acetic acid. All eluents were filtered through $0.45 \mu \mathrm{m}$ nylon filters (Millipore, Molsheim, France). The flow rate was set at $1.0 \mathrm{~mL} \cdot \mathrm{min}^{-1}$ for the duration of the run. A gradient run was programmed as follows: $15 \%$ A for $1.1 \mathrm{~min}, 15 \%$ to $45 \%$ over the next $21.1 \mathrm{~min}$, then $45 \%$ to $100 \%$ A over the next one min, and then hold at $100 \% \mathrm{~A}$ for the next $14 \mathrm{~min}$. The gradient was returned to the initial $15 \% \mathrm{~A}: 85 \% \mathrm{~B}$ over the next $1.0 \mathrm{~min}$., and the column was conditioned at that setting for the next $12.9 \mathrm{~min}$ until the next sample was injected.

Compounds were detected on a photodiode array detector set at $254 \mathrm{~nm}$. Data were collected and peaks integrated using Millenium Chromatography Software (Version 3.05; Waters corp.). Peaks were assigned by comparing retention times of authentic standards prepared as described in Lancaster and Kelly (1983) and Randle et al. (1995)

Statistical analysis. Data were subjected to the GLM procedure and linear and polynomial regression analyses when appropriate, using SAS statistical software. (Version 8.2, SAS institute, Cary, N.C.). Percentage data were tested for normality, and arcsin transformations were performed. Contrasts among the treatments were done using Scheffe's method of multiple comparisons.

\section{Results and Discussion}

Plant growth Response. Early in the experiment, no growth differences were observed among various treatments. As onions entered their tenth week of growth, visible differences were observed between the low- $\mathrm{N}$ treatment and all others, regardless of S level. Plants grown with $10 \mathrm{mg} \cdot \mathrm{L}^{-1} \mathrm{~N}$, had fewer leaves and exhibited yellowing. At that time $\mathrm{S}$ did not visibly appear to be influencing growth. Near the end of the experiment ( $\approx 15$ weeks) we observed that plants exposed to low-N levels $\left(10 \mathrm{mg} \cdot \mathrm{L}^{-1} \mathrm{~N}\right)$ matured early and had uniformly small bulbs, regardless of $\mathrm{S}$ level. At this time, plants exposed to low-S $\left(5 \mathrm{mg} \cdot \mathrm{L}^{-1} \mathrm{SO}_{4}{ }^{2-}\right)$ had visibly smaller bulbs across $\mathrm{N}$ levels.

BULB FRESH WEIGHT. Bulb FW was influenced by $S(P<0.001$, $\mathrm{F}=25.1)$ and $\mathrm{N}(P<0.001, \mathrm{~F}=35.0)$ availability in the solution (Table 1). Additionally, $\mathrm{S}$ and $\mathrm{N}$ fertility interacted to influence bulb FW $(P<0.001, \mathrm{~F}=5.1)$ Average bulb FW varied from 96 to $206 \mathrm{~g} /$ bulb (Fig. 1A) and responded quadratically to changes in $\mathrm{S}$ and $\mathrm{N}$ availability (Table 2). Not surprisingly, plants grown at the lowest levels of $\mathrm{S}$ and $\mathrm{N}$ produced bulbs of the smallest FWs; although when plants were grown in $10 \mathrm{mg} \cdot \mathrm{L}^{-1} \mathrm{~N}$, bulb FWs were depressed, regardless of S levels Similarly, Freeman and Mossadeghi (1970) reported that low S fertility in a sand culture system could negatively influence bulb FW. Randle (2000) reported that bulb FW decreased with increasing $\mathrm{N}$ availability in solution culture; however, in that study, plants were grown at very high levels of $\mathrm{N}$, and it was suspected that high $\mathrm{N}$ levels produced excessive foliage at the expense of bulb yield.

Total Bulbs. Both $\mathrm{S}$ and $\mathrm{N}$ levels in the nutrient solution interacted to affect total bulb $\mathrm{S}(P<0.001, \mathrm{~F}=28.4)($ Fig $1 \mathrm{~B})$. 
Table 2. The regression responses for the effect of sulfate and nitrogen availability on the average bulb fresh weight (FW), total bulb sulfur (TS), total $S$-alk(en)yl-L-cysteine-sulfoxides (ACSO), $S$-methyl-L-cysteine sulfoxide (MCSO), trans-S-1-propenyl-L-cysteine sulfoxide (1-PRENCSO), $S$-propyl-L-cysteine sulfoxide (PCSO), 2 carboxypropyl glutathione (2-Carb), and gammaglutamyl-1-propenyl cysteine sulfoxide ( $\gamma$ GPECSO) concentrations in hydroponically grown 'Granex 33' onion bulbs. In the equations: sulfate (S), nitrogen (N), sulfate $\times$ nitrogen $(\mathrm{SN})$.

\begin{tabular}{lll}
\hline Response & Regression equation & $R^{2}$ \\
\hline FW & FW $=73.3+2.85 \mathrm{~N}-0.02 \mathrm{~N}^{2}+0.002 \mathrm{SN}$ & 0.74 \\
TS & $\mathrm{TS}=0.14+0.005 \mathrm{~S}-0.00004 \mathrm{~S}^{2}+0.00002 \mathrm{SN}$ & 0.80 \\
ACSO & $\mathrm{ACSO}=0.74+0.04 \mathrm{~N}-0.0002 \mathrm{~N}^{2}-0.00003 \mathrm{SN}$ & 0.80 \\
MCSO & $\mathrm{MCSO}=0.24+0.04 \mathrm{~N}-0.0002 \mathrm{~N}^{2}$ & 0.81 \\
1 -PRENCSO & $1-\mathrm{PRENCSO}=0.26+0.01 \mathrm{~S}-0.00009 \mathrm{~S}^{2}-0.00001 \mathrm{~N}^{2}+0.00004 \mathrm{SN}$ & 0.78 \\
PCSO & $\mathrm{PCSO}=0.08+0.002 \mathrm{~N}-0.000005 \mathrm{SN}$ & 0.53 \\
2 -Carb & 2 -Carb $=0.34+0.01 \mathrm{~N}-0.00007 \mathrm{~N}^{2}+0.00002 \mathrm{SN}$ & 0.69 \\
$\gamma$ GPECSO & $\gamma \mathrm{GPECSO}=0.004+0.005 \mathrm{~N}-0.00003 \mathrm{~N}^{2}+0.00002 \mathrm{SN}$ & 0.58 \\
\hline
\end{tabular}

${ }^{\mathrm{z}}$ Significance at $P<0.001$.

Individually, $\mathrm{S}(P<0.001, \mathrm{~F}=285.8)$ and $\mathrm{N}(P<0.001, \mathrm{~F}=29.4)$ levels significantly influenced total bulb $\mathrm{S}$ (Table 1$)$. Average total bulb $\mathrm{S}$ ranged from $0.14 \%$ to $0.47 \%$ dry-weight (Fig. 1B). Randle et al. (1999) also reported a 3-fold increase in total bulb S in response to increasing $\mathrm{S}$ fertility; whereas, minimal changes in total bulb $\mathrm{S}$ were observed in onions grown over several high $\mathrm{N}$ levels (Randle, 2000). Similarly, while plants grown at the lowest $\mathrm{S}$ or N levels had uniformly low levels of total bulb S $(0.14 \%$ to $0.20 \%)$, bulb S rose linearly with $\mathrm{S}$ concentrations in the solution, while the response of bulb $\mathrm{S}$ to $\mathrm{N}$ levels above 10 $\mathrm{mg} \cdot \mathrm{L}^{-1}$ was more variable. Our data suggest that low-N fertility depressed bulb total $\mathrm{S}$ accumulation much in the way that low-S fertility did (Randle et al., 1995), hence the significant interaction. Bulb FW was closely correlated to total $\mathrm{S}(r=0.72)$, and bulbs grown at low-S or low-N were unusually small; therefore, it is likely that the lowest $\mathrm{S}$ and $\mathrm{N}$ levels limited plant metabolism, thus decreasing the need for excess $\mathrm{S}$ which is often sequestered in the flavor biosynthetic pathway.

INTACT FLAVOR PRECURSORS AND $\gamma$ GP INTERMEDIATES. Total ACSOs are simply the sum of the three individual ACSOs measured, and are useful in describing the net effect of treatments on the flavor pathway in onions. Though $\mathrm{N}$ and $\mathrm{S}$ levels interacted to influence individual ACSOs, only $\mathrm{N}$ fertility significantly influenced total ACSO accumulation $(P<0.001$, $\mathrm{F}=50.3)($ Fig 2A). Levels of total ACSOs in the bulb ranged from 1.07 to $2.81 \mathrm{mg} \cdot \mathrm{g}^{-1} \mathrm{FW}$, responding quadratically to $\mathrm{N}$ levels (Table 2), increasing sharply between 10 and $50 \mathrm{mg} \cdot \mathrm{L}^{-1}$ $\mathrm{N}$ and then leveling off (Table 3). Single degree of freedom contrasts between $\mathrm{N}$ levels indicated that plants grown at $10 \mathrm{mg} \cdot \mathrm{L}^{-1} \mathrm{~N}$, had significantly lower $(P<0.05)$ levels of

Fig. 2. The effects of solution sulfate $\left(\mathrm{SO}_{4}{ }^{2-}\right)$ and nitrogen (N) availability on the levels of total $S$-alk(en)yl-Lcysteine-sulfoxides (ACSO) (A), S-methyl-L-cysteine sulfoxide (MCSO) (B), trans-S-1-propenyl-L-cysteine sulfoxide (1-PRENCSO) (C), S-propyl-L-cysteine sulfoxide (PCSO) (D), 2 carboxypropyl glutathione (2-Carb) (E), and gammaglutamyl-1-propenyl cysteine sulfoxide $(\gamma$ GPECSO) $(\mathbf{F})$ in hydroponically grown 'Granex 33' onions. total ACSOs in the bulb than all other N levels. Total ACSOs did not differ in bulbs grown at 50, 90 and $130 \mathrm{mg} \cdot \mathrm{L}^{-1} \mathrm{~N}$.

Both $\mathrm{S}(P<0.001, \mathrm{~F}=13.9)$ and $\mathrm{N}(P<0.001, \mathrm{~F}=52.8)$ fertility individually influenced the accumulation of MCSO in the bulb; however, they did not interact to affect MCSO concentrations (Table 3). Bulb MCSO content ranged from 0.57 to 1.91 $\mathrm{mg} \cdot \mathrm{L}^{-1} \mathrm{FW}$, and generally increased with rising $\mathrm{N}$ levels, but fell

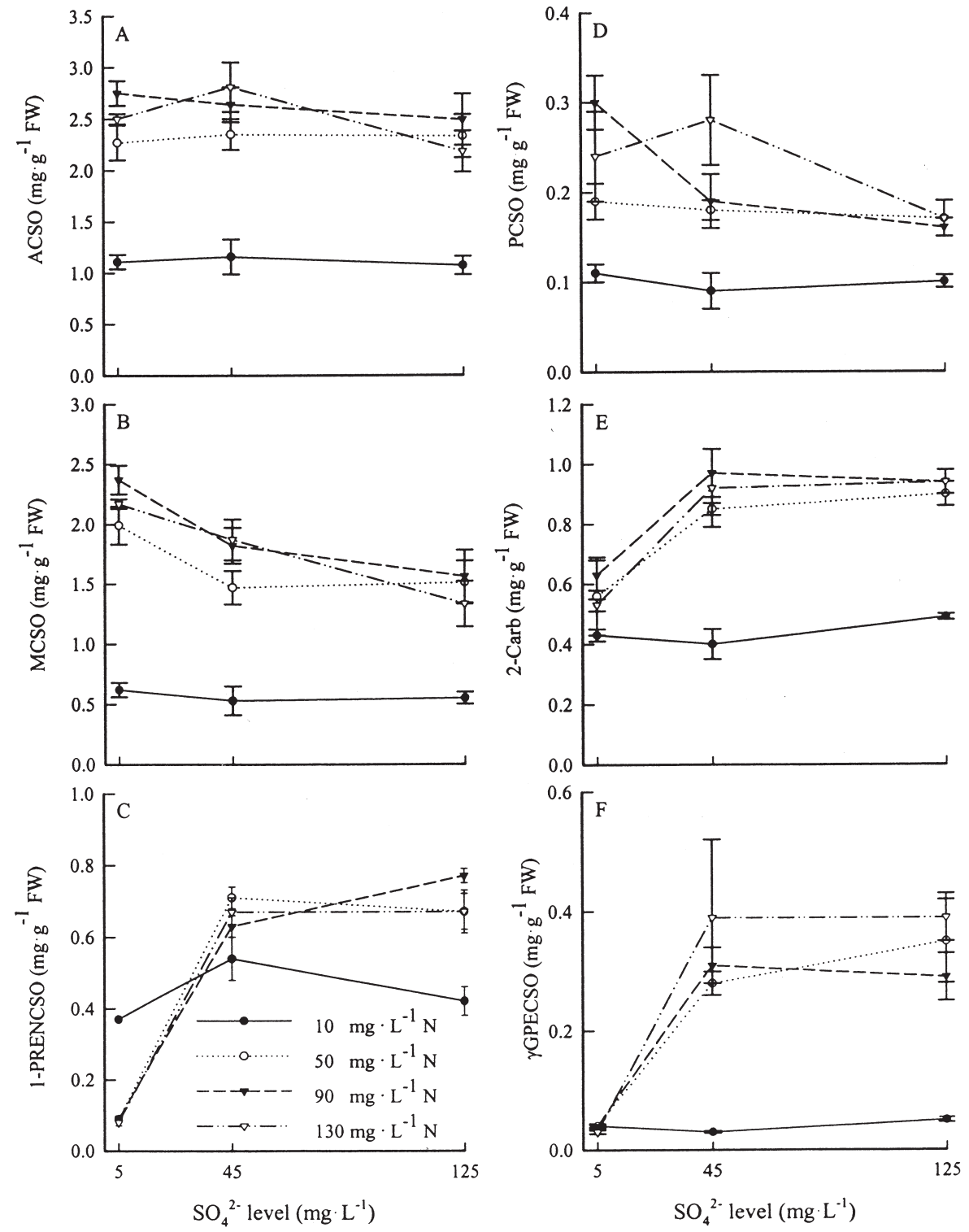


Table 3. The effects of sulfate $\left(\mathrm{SO}_{4}{ }^{2-}\right)$ and nitrogen $(\mathrm{N})$ availability levels in solution on marginal means and standard errors for total $S$-alk(en)ylL-cysteine-sulfoxides (ACSO), $S$-methyl-L-cysteine sulfoxide (MCSO), trans-S-1-propenyl-L-cysteine sulfoxide (1-PRENCSO), S-propylL-cysteine sulfoxide (PCSO), 2 carboxypropyl glutathione (2-Carb), and gammaglutamyl-1-propenyl cysteine sulfoxide ( $\gamma$ GPECSO) in hydroponically grown 'Granex 33' onions.

\begin{tabular}{|c|c|c|c|c|c|c|}
\hline \multirow[b]{2}{*}{ Solution } & \multicolumn{6}{|c|}{ Chemical $\left(\mathrm{mg} \cdot \mathrm{g}^{-1}\right.$ fresh wt) } \\
\hline & ACSO & MCSO & 1-PRENCSO & PCSO & 2-Carb & $\gamma$ GPECSO \\
\hline \multicolumn{7}{|c|}{$\mathrm{SO}_{4}{ }^{2-}\left(\mathrm{mg} \cdot \mathrm{L}^{-1}\right)$} \\
\hline 5 & $2.13 \pm 0.18$ & $1.76 \pm 0.19$ & $0.16 \pm 0.03$ & $0.21 \pm 0.02$ & $0.54 \pm 0.02$ & $0.04 \pm 0.002$ \\
\hline \multirow[t]{2}{*}{125} & $2.02 \pm 0.17$ & $1.24 \pm 0.13$ & $0.63 \pm 0.04$ & $0.15 \pm 0.01$ & $0.82 \pm 0.05$ & $0.27 \pm 0.04$ \\
\hline & NS & $* * *$ & $* * *$ & $*$ & $* * *$ & $* * *$ \\
\hline \multicolumn{7}{|c|}{$\mathrm{N}\left(\mathrm{mg} \cdot \mathrm{L}^{-1}\right)$} \\
\hline 90 & $2.63 \pm 0.10$ & $1.91 \pm 0.13$ & $0.50 \pm 0.09$ & $0.21 \pm 0.02$ & $0.83 \pm 0.06$ & $0.20 \pm 0.04$ \\
\hline \multirow[t]{2}{*}{130} & $2.50 \pm 0.13$ & $1.76 \pm 0.14$ & $0.51 \pm 0.09$ & $0.23 \pm 0.03$ & $0.82 \pm 0.07$ & $0.29 \pm 0.06$ \\
\hline & $* * *$ & $* * *$ & NS & $* * *$ & $* * *$ & $* * *$ \\
\hline
\end{tabular}

ss,*****Nonsignificant or significant at $P=0.05$ and 0.001 respectively.

Table 4. The effects of sulfate $\left(\mathrm{SO}_{4}^{2-}\right)$ and nitrogen $(\mathrm{N})$ levels on the marginal means and standard errors for intact total $S$-alk(en)yl-L-cysteinesulfoxides (ACSO), S-methyl-L-cysteine sulfoxide (MCSO), trans-S-1-propenyl-L-cysteine sulfoxide (1-PRENCSO), $S$-propyl-L-cysteine sulfoxide (PCSO), hydrolyzed by alliinase in the onion macerate. The percentage of the total intact precursor, which was hydrolyzed by alliinase is listed in parenthesis to the right of each precursor.

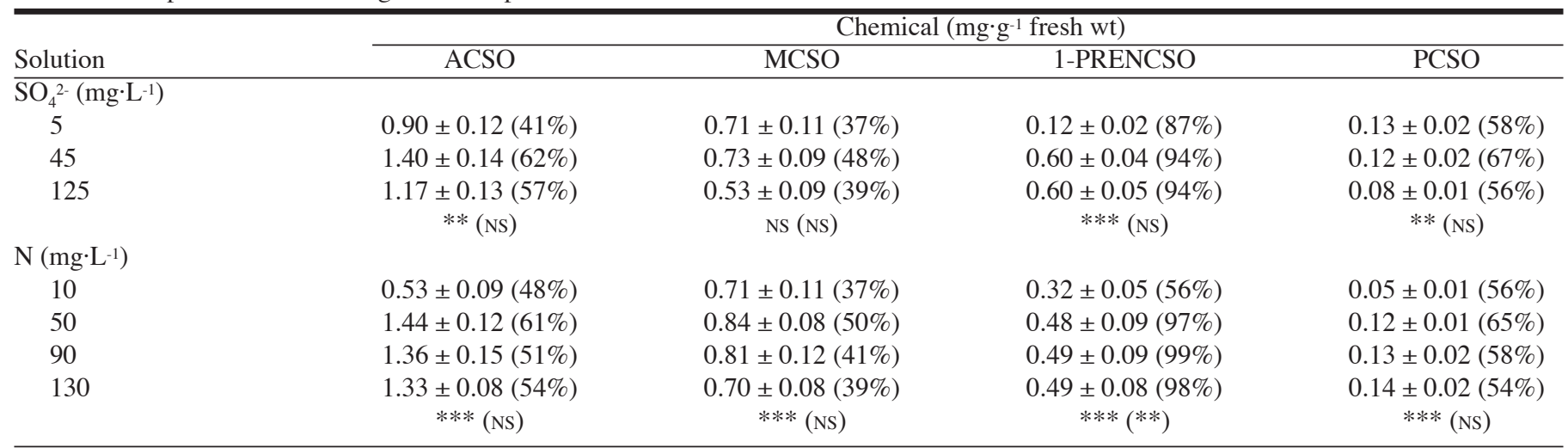

Ns,**,****Nonsignificant or significant at $P=0.05$ and 0.001 respectively.

with increasing S (Fig 2B). Similar responses of bulb MCSO concentrations to $\mathrm{S}$ or $\mathrm{N}$ fertility have been previously reported (Randle, 2000; Randle et al., 1995). Although S was shown to significantly affect MCSO concentrations according to the GLM procedure, it did not contribute significantly to the regression response, which when fitted, showed only a quadratic response to $\mathrm{N}$ concentration in the solution (Table 2). Consequently, MCSO concentrations increased nearly $250 \%$ across $\mathrm{N}$ treatment levels, while similarly spaced changes in $\mathrm{SO}_{4}{ }^{2-}$ availability resulted in smaller, $12 \%$ to $65 \%$, changes in MCSO (Fig. 2B). Our data suggests that $\mathrm{N}$, and not $\mathrm{S}$ availability, had the greatest impact on bulb MCSO concentrations. We have not measured the possible changes in the peptides leading to the synthesis of MCSO, as many of the intermediates in the MCSO pathway have not been routinely identified in vivo.

Solution $\mathrm{S}$ levels significantly influenced bulb 1-PRENCSO concentrations $(P<0.001, \mathrm{~F}=215.8)$, but the main effects of solution $\mathrm{N}$ were insignificant (Table 3 ). Furthermore, $\mathrm{S}$ and $\mathrm{N}$ interacted to significantly influence 1-PRENCSO concentrations in the bulb $(P<0.001, \mathrm{~F}=17.55)$. For those plants grown at either 50,90 or $130 \mathrm{mg} \cdot \mathrm{L}^{-1} \mathrm{~N}$, concentrations of 1-PRENCSO

Fig. 3. The effects of solution sulfate $\left(\mathrm{SO}_{4}{ }^{2-}\right)$ and nitrogen $(\mathrm{N})$ levels on the percentage (\%) of intact trans-S-1-propenyl-L-cysteine sulfoxide (1-PRENCSO) hydrolyzed by alliinase in the onion macerate. increased $\approx 7$-fold as $\mathrm{SO}_{4}{ }^{2-}$ levels in the solutions rose from 5 to $45 \mathrm{mg} \cdot \mathrm{L}^{-1}$ (Fig. 2C). Levels of 1-PRENCSO were unaffected between 45 and $125 \mathrm{mg} \cdot \mathrm{L}^{-1} \mathrm{SO}_{4}{ }^{2-}$, regardless of $\mathrm{N}$ level (Fig. $2 \mathrm{C})$. Interestingly, $\mathrm{S}$ levels in the solution did little to change 1PRENCSO concentrations in bulbs when plants were grown at

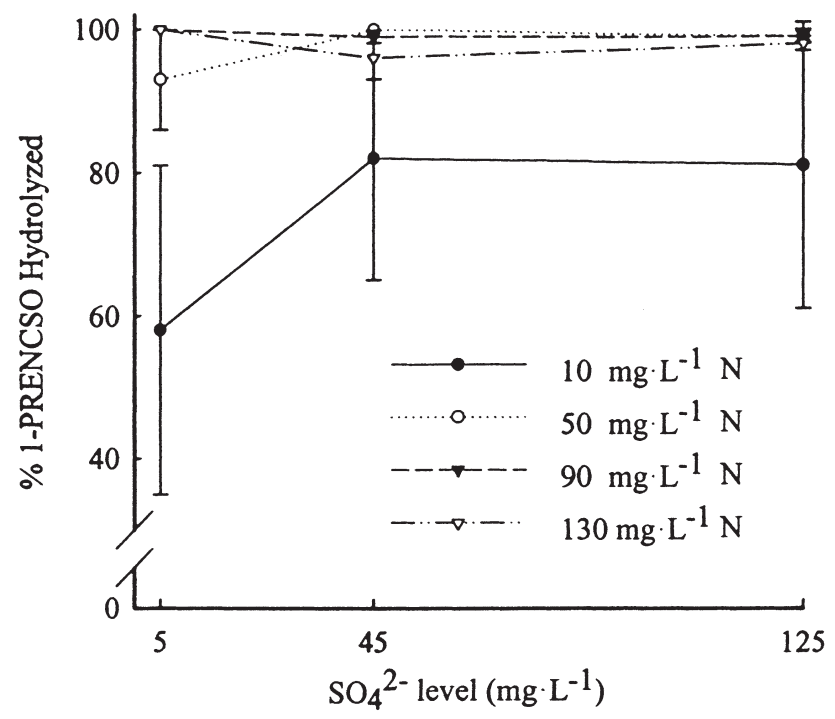


$10 \mathrm{mg} \cdot \mathrm{L}^{-1} \mathrm{~N}$. This suggests that while $\mathrm{S}$ and $\mathrm{N}$ levels do interact to influence 1-PRENCSO in the bulb, the $\mathrm{S}$ level in a solution has a much greater effect on 1-PRENCSO than does $\mathrm{N}$ level. Randle et al. (1995) similarly reported large changes in 1-PRENCSO concentrations in response to $\mathrm{S}$ fertility levels with sufficient $\mathrm{N}$, but noted much smaller changes in 1-PRENCSO in response to $\mathrm{N}$ fertility with sufficient $\mathrm{S}$ levels (Randle, 2000).

Both $\mathrm{S}(P<0.012, \mathrm{~F}=5.2)$ and $\mathrm{N}(P<0.001, \mathrm{~F}=16.4)$ fertility levels influenced bulb PCSO concentrations (Table 3). Additionally, there was a significant interaction between $\mathrm{S}$ and $\mathrm{N}$ fertility, affecting bulb concentrations of PCSO $(P<0.03$, $\mathrm{F}=2.7)$. Generally, PCSO levels in the bulb increased as the availability of $\mathrm{N}$ increased but fell as $\mathrm{S}$ fertility increased (Fig. 2D). Bulb concentrations of PCSO are typically much lower than either MCSO or 1-PRENCSO (Kopsell et al., 2001; Kopsell and Randle, 1999; Randle, 2000). However, in this experiment, PCSO concentrations were higher than those of 1-PRENCSO for bulbs grown at $5 \mathrm{mg} \cdot \mathrm{L}^{-1} \mathrm{SO}_{4}{ }^{2-}$ and either 50,90 , or $130 \mathrm{mg} \cdot \mathrm{L}^{-1} \mathrm{~N}$ (Table $3)$. Randle et al. (1995) reported similar results in plants grown with $0.10 \mathrm{meq} \cdot \mathrm{L}^{-1} \mathrm{~S}$ fertility.

The pathway leading to the synthesis of PCSO in onion is similar to that of 1-PRENCSO as they share several intermediates. Therefore, it is noteworthy that the synthesis of one of these precursors is favored over the other under conditions of low-S and adequate- $\mathrm{N}$ availability in the nutrient solutions. Because the ratio of PCSO to 1-PRENCSO changes with $\mathrm{S}$ and $\mathrm{N}$ fertility, it seems probable that a point of regulation in the synthesis of PCSO versus 1-PRENCSO occurs when $\gamma$ glutamyl- $S$-1-propenyl cysteine, which is reported to be the last common intermediate, diverges to form either PCSO or 1-PRENCSO. A detailed review of the synthesis and chemistry of the ACSOs can be found in Randle and Lancaster (2002) or Block (1992).

Apart from the implications for onion flavor quality, the response of the individual flavor precursors to $\mathrm{S}$ and $\mathrm{N}$ availability provided some insight into the metabolic regulation of the entire ACSO pathway. Our data suggest that the pathway leading to the synthesis of MCSO is regulated primarily by N availability, whereas the synthesis of 1-PRENCSO is regulated to a greater extent by $\mathrm{S}$ availability. Previous research further supports our findings (Randle 2000; Randle et al., 1995). It is an interesting question as to why the individual ACSOs are influenced differently by either $\mathrm{S}$ or $\mathrm{N}$ nutrition. It is also unclear the advantage conferred to the plant when a particular ACSO is preferred in these different situations.

Two peptide intermediates, 2-Carb and $\gamma \mathrm{GPECSO}$, were measured in response to $\mathrm{S}$ and $\mathrm{N}$ nutrition. Concentrations of 2-Carb were influenced by $\mathrm{S}(P<0.001, \mathrm{~F}=31.1)$ and $\mathrm{N}(P<$ $0.001, \mathrm{~F}=36.1$ ) availability in the solution (Table 3 ). Additionally, both nutrients interacted to influence levels of 2-Carb in the bulb $(P<0.002, \mathrm{~F}=3.5)$, which tended to increase as both $\mathrm{S}$ and $\mathrm{N}$ concentrations rose (Fig. 2E). Concentrations of 2-Carb in the bulb ranged from 0.43 to $0.97 \mathrm{mg} \cdot \mathrm{g}^{-1} \mathrm{FW}$ and were highly correlated to total bulb $\mathrm{S}(r=0.85)$. This would be expected as 2-Carb has been hypothesized to be a storage reservoir for $\mathrm{N}$ and $\mathrm{S}$ in the bulb (Lancaster and Shaw, 1991). Interestingly, 2-Carb is an intermediate in the production of both 1-PRENCSO and PCSO; however, correlations between 2-Carb and 1-PRENCSO $(r=0.61)$ or 2 -Carb and PCSO $(r=0.41)$ were poor.

Bulb $\gamma$ GPECSO levels responded significantly to $\mathrm{S}(P<0.001$, $\mathrm{F}=49.2)$ and $\mathrm{N}(P<0.001, \mathrm{~F}=23.9)$ fertility. Similar to 2 -Carb, $\mathrm{S}$ and $\mathrm{N}$ fertility levels interacted to influence levels of $\gamma \mathrm{GPECSO}$ in the bulb $(P<0.001, \mathrm{~F}=6.1)$. Generally, $\gamma \mathrm{GPECSO}$ concen- trations increased with $\mathrm{N}$ and $\mathrm{S}$ fertility, in much the way as the levels of 2-Carb. However, roughly a ten-fold difference was observed between the lowest and highest levels of $\gamma$ GPECSO in the bulb, whereas 2-Carb concentrations doubled (Fig. 2F). Additionally, concentrations of $\gamma$ GPECSO and 1-PRENCSO were highly correlated $(r=0.73)$, which was expected, as $\gamma$ GPECSO is the penultimate peptide in the synthesis of 1-PRENCSO. Previously it has been reported that $\gamma$ GPECSO, like 2-Carb, functions as a storage reservoir for $\mathrm{S}$ and $\mathrm{N}$ in the bulb (Lancaster and Shaw, 1991). Levels of $\gamma$ GPECSO remained high in the bulb, even when concentrations of 1-PRENCSO were relatively high and accumulated in large amounts, which supports the claim that $\gamma$ GPECSO functions as $\mathrm{S}$ and $\mathrm{N}$ reserve in the bulb. Additionally, Kopsell et al. (2002) reported that $\gamma$ GPECSO likely contributes to production of the lachrymatory factor in onions, and thus changes in $\gamma$ GPECSO content may affect flavor attributes of the bulb.

Because neither 2-Carb nor $\gamma$ GPECSO is thought to be involved in the production of MCSO, it therefore could be reasoned that increases in MCSO would lead to a corresponding decrease in either peptide, because a limited amount of $\mathrm{S}$ is partitioned into the production of MCSO instead of 1-PRENCSO or PCSO. However, correlations between MCSO and either 2-Carb $(r=$ $0.41)$ or $\gamma \mathrm{GPECSO}(r=0.22)$ were poor, and do not support this assumption.

ACSOs IN THE ONION MACERATE. When onion cells are disrupted and vacuoles lysed, the enzyme alliinase is released and individual ACSOs are hydrolyzed to form several sulfenic acids and thiosulfinates. Each ACSO contributes to thiosulfinates that lend unique flavor characteristics upon degradation. Upon hydrolysis, MCSO tends to impart a cabbage-like and fresh onion flavor sensation, whereas the hot burning sensations commonly associated with cooking onions can be attributed to the hydrolysis of 1-PRENCSO.PCSO has been reported to confer fresh onion and chive-like flavor sensations upon hydrolysis by alliinase (Randle et al., 1994). Because it is difficult to quantify the thiosulfinates and lachrymatory factor, we have chosen to measure the ACSOs remaining in the onion macerate to gain a better understanding of how the individual ACSOs contribute to the flavor of onions (Kopsell et al., 2002; Randle et al., 1994). If the level of ACSOs remaining in the macerate is subtracted from levels of intactACSOs we can also determine the extent of alliinase activity.

Levels of total ACSOs hydrolyzed were affected by $\mathrm{S}(P<$ $0.004, \mathrm{~F}=6.6)$ and $\mathrm{N}(P<0.001, \mathrm{~F}=16.3)$ fertility levels (Table 4). A significant interaction was not detected. Levels of degraded ACSOs ranged from 0.41 to $1.69 \mathrm{mg} \cdot \mathrm{g}^{-1} \mathrm{FW}$. Not surprisingly, the general response to $\mathrm{N}$ concentrations was for levels of hydrolyzed ACSOs to increase as N solution levels increased, similar to the overall trend for intact ACSO accumulation. The effects of $\mathrm{S}$ availability on levels of degraded ACSOs were slightly different, as the highest levels of hydrolyzed ACSOs occurred in the macerate from bulbs grown at $45 \mathrm{mg} \cdot \mathrm{L}^{-1} \mathrm{SO}_{4}{ }^{2-}$. The relative percentage of intact ACSOs hydrolyzed varied from $41 \%$ to $62 \%$; however, large variations in the hydrolysis of ACSOs likely led to a nonsignificant response to either $\mathrm{S}$ or $\mathrm{N}$ fertility here (Table 4).

Average levels of hydrolyzed MCSO ranged from 0.70 to 0.84 $\mathrm{mg} \cdot \mathrm{g}^{-1} \mathrm{FW}$, and were significantly influenced by $\mathrm{N}$ levels in the hydroponics solution $(P<0.001 \mathrm{~F}=10.1)$ (Table 4). Hydrolyzed MCSO was not significantly influenced by $\mathrm{S}$ levels or by an $\mathrm{S}$ and $\mathrm{N}$ interaction. Lancaster et al. (1998), however, did show a significant response of MCSO hydrolysis to S fertility. Generally, those bulbs grown at the lowest level of $\mathrm{N}$ had the least amount of MCSO degraded, which was expected, as those bulbs had the 
least amount of total intact MCSO. The percentage of MCSO hydrolyzed ranged from $37 \%$ to $50 \%$, but again, due to high variability in the hydrolysis of MCSO in the macerate, the effects of either $\mathrm{S}$ or $\mathrm{N}$ on MCSO hydrolysis were not significant.

Average levels of 1-PRENCSO hydrolyzed by alliinase ranged from 0.12 to $0.60 \mathrm{mg} \cdot \mathrm{g}^{-1} \mathrm{FW}$ (Table 4$)$. In this case, $\mathrm{S}$ and $\mathrm{N}$ availability significantly interacted $(P<0.001, \mathrm{~F}=6.4)$ to influence the level of 1-PRENCSO hydrolyzed in the macerate. In addition, as a main effect, $\mathrm{S}$ availability had a significant influence $(P<$ $0.001, \mathrm{~F}=105.5$ ) on levels of 1-PRENCSO hydrolyzed, as was the case with the accumulation of intact 1-PRENCSO (Table 4). Lancaster et al. (1998) reported near complete hydrolysis of 1-PRENCSO in the onion macerate. Similarly, we observed levels of 1-PRENCSO hydrolysis near $100 \%$ for bulbs grown in all treatment combinations other than $10 \mathrm{mg} \cdot \mathrm{L}^{-1} \mathrm{~N}$. However, the hydrolysis of 1-PRENCSO in the macerate of bulbs grown in the lowest $\mathrm{N}$ levels was significantly lower $(P<0.01, \mathrm{~F}=4.26)$ ranging from $58 \%$ to $82 \%$ suggesting that alliinase activity is affected by low $\mathrm{N}$ fertility (Fig 3 ).

Levels of PCSO hydrolyzed in the macerate were influenced by $\mathrm{S}(P<0.01, \mathrm{~F}=5.6)$ and $\mathrm{N}(P<0.001, \mathrm{~F}=10.0)$ availability in the nutrient solution; however, a significant interaction was not present. Hydrolyzed PCSO ranged from 0.05 to $0.14 \mathrm{mg} \cdot \mathrm{g}^{-1} \mathrm{FW}$, with the overall trend being to increase hydrolysis as $\mathrm{N}$ fertility increased and as S fertility decreased (Table 4), much like the accumulation of intact PCSO in the bulb. The relative percentage of PCSO hydrolyzed averaged $60 \%$ and was not significantly influenced by either $\mathrm{S}$ or $\mathrm{N}$ levels. The percentage degraded here was slightly higher than those previously reported by Lancaster et al. (1998).

Previous investigations into alliinase activity in vitro have shown that 1-PRENCSO is preferentially hydrolyzed over both MCSO and PCSO (Nock and Mazelis, 1987; Schwimmer, 1969). Additionally, Lancaster et al. (1998) reported that alliinase acts differently on each of the individual ACSOs in vivo. In general, 1-PRENCSO was more completely hydrolyzed than was either MCSO or PCSO. Therefore, 1-PRENCSO would tend to contribute more to the actual flavor of an onion than would the other two ACSOs on a FW basis. Our data concur with these findings, as the percentage of 1-PRENCSO hydrolyzed in the macerate was higher than MCSO and PCSO at all treatment levels except one. However, unlike the other ACSOs, the level of 1-PRENCSO hydrolysis, was influenced by low $\mathrm{N}$ fertility (Fig 3 ). This suggests that low-N (10 mg. $\left.\mathrm{L}^{-1}\right)$ availability decreased the activity levels of alliinase for 1-PRENCSO, which could be explained by the existence of alliinase isozymes (Lancaster et al., 2000; Nock and Mazelis, 1987). Therefore, flavor was influenced by $\mathrm{S}$ or $\mathrm{N}$ fertility in two ways. One, by changing total levels of intact ACSOs in the bulb, and two, the activity of alliinase may be altered via fertility changes.

Our purpose was to document how $\mathrm{S}$ and $\mathrm{N}$ availability interacted to influence the biosynthetic flavor pathway in onion. Low $\mathrm{SO}_{4}{ }^{2-}$ or $\mathrm{N}$ fertility levels similarly reduced levels of ACSOs and $\gamma \mathrm{GPs}$ in the bulb, with the exception of MCSO. At the lowest levels, bulb FW was significantly reduced compared to the other treatments. Furthermore, $\mathrm{N}$ level had a greater effect on the synthesis of MCSO. Conversely, $\mathrm{SO}_{4}^{2-}$ levels had a greater influence on the synthesis of 1-PRENCSO. Our data also suggest that the largest changes in concentrations of the ACSOs and $\gamma$ GPs in the bulb occurs in plants grown at the lowest levels of $\mathrm{SO}_{4}{ }^{2-}$ and N. Only minor differences appear in bulbs from plants grown at the higher levels of $\mathrm{SO}_{4}{ }^{2-}$ and $\mathrm{N}$. Thus, the effect of each nutri- ent on the flavor pathway diminishes as each becomes present in adequate or luxuriant levels. Additionally, because each ACSO will impart different flavor sensations, varying $\mathrm{S}$ and $\mathrm{N}$ levels may have implications for flavor quality in the bulb.

\section{Literature Cited}

Armstrong, M.D. and J.D. Lewis. 1951. Thioether derivatives of cysteine and homocysteine. J. Organic Chem. 16:749-753.

Block, E. 1992. The organosulfur chemistry of the genus Allium-Implications for the organic chemistry of sulfur. Angew Chem. Intl. Ed. Eng. 31:1135-1178.

Brewster J.L. and H.A. Butler. 1989. Effects of nitrogen supply on bulb development in onion (Allium cepa L.). J. Expt. Bot. 219:1155-1162.

Brown, B.D., A.J. Hornbacher, and D.V. Naylor. 1988. Sulfur-coated urea as a slow-release nitrogen source for onions. J. Amer. Soc. Hort. Sci. 113:864-869.

Brunold, C. and M. Suter. 1984. Regulation of sulfate assimilation by nitrogen nutrition in the duckweed Lemna minor L. Plant Physiol. 76:579-583.

Coolong, T.W. 2003. Temperature, nitrogen and sulfur fertility influence the flavor pathway in onion (Allium cepa L.) MS thesis. Univ. Ga., Athens.

Drost, D., R. Koenig, and T. Tindall. 2002. Nitrogen use efficiency and onion yield increased with a polymer-coated nitrogen source. HortScience 37:338-342.

Freeman, G.G. and N. Mossadeghi. 1970. Effect of sulphate nutrition on flavour components of onion (Allium cepa). J. Sci. Food Agr. 21: 610-615.

Gamiely, S., W.M. Randle, H.A. Mills, D.A. Smittle, and G.I. Banna. 1991. Onion plant growth, bulb quality, and water uptake following ammonium and nitrate nutrition. HortScience 26:1061-1063.

Hamilton, B.K., L.M. Pike, and K.S. Yoo. 1997. Clonal variations of pungency, sugar content, and bulb weight of onions due to sulphur nutrition. Scientia Hort. 71:131-136.

Hell, R. 1997. Molecular physiology of plant sulfur metabolism. Planta 202:138-148.

Hoagland, D.R. and D.I. Arnon. 1950. The water culture method for growing plants without soil. Calif. Agr. Expt. Sta. Circ. 347.

Hussaini, M.A., E.B Amans, and A.A. Ramalan. 2000. Yield, bulb size distribution, and storability of onion (Allium cepa L.) under different levels of $\mathrm{N}$ fertilization and irrigation regime. Trop. Agr. 77:145-149.

Koprivova, A., M.S. Suter, R.O.den Camp, C. Brunold, and S. Kopriva. 2000. Regulation of sulfate assimilation by nitrogen in Arabidopsis. Plant Physiol. 122:737-746.

Kopsell, D.A. and W.M. Randle. 1999. Selenium affects the S-alk(en)yl cysteine sulfoxides among short-day onion cultivars. J. Amer. Soc. Hort. Sci. 124:307-311.

Kopsell, D.A., W.M. Randle, and M.A. Eitemen. 2001. Changes in Salk(en)yl cysteine sulfoxides and precursor intermediates during storage among short and long day onion cultivars. Acta Hort. 555:153-156.

Kopsell, D.E, W.M. Randle, and N.E. Schmidt. 2002. Incubation time, cultivar, and storage duration affect onion lachrymatory factor quantification. HortScience 37:567-570.

Lancaster, J.E. and K.E. Kelly. 1983. Quantitative analysis of the Salk(en)yl-L-cysteine sulphoxides in onion (Allium cepa L.). J. Sci. Food Agr. 34:1229-1235.

Lancaster, J.E. and M.L. Shaw. 1991. Metabolism of $\gamma$-glutamyl peptides during development, storage and sprouting of onion bulbs. Phytochemistry 30:2857-2859.

Lancaster, J.E., M.L. Shaw, M.D.P. Joyce, J.A. McCallum, and M.T. McManus. 2000. A novel alliinase from onion roots. Biochemical characterization and cDNA cloning. Plant Physiol. 122:1269-1279.

Lancaster, J.E., M.L. Shaw, and W.M. Randle. 1998. Differential hydrolysis of alk(en)yl cysteine sulphoxides by alliinase in onion macerates: flavour implications. J. Sci. Food Agr. 78:367-372.

Leustek, T., M.N. Martin, J.A. Bick, and J.P. Davies. 2000. Pathways and regulation of sulfur metabolism revealed through molecular and genetic 
studies. Annu. Rev. Plant Physiol. Plant Mol. Biol. 51:141-165.

Nock, L.P. and M. Mazelis. 1987. The C-S lysases of higher plants: direct comparison of the physical properties of homogeneous alliin lyase of garlic (Allium sativum) and onion (Allium cepa). Plant Physiol. 85: 1079-1083.

Pinkerton, A. 1998. Critical sulfur concentrations in oilseed rape (Brassica napus) in relation to nitrogen supply and to plant age. Austral. J. Expt. Agr. 38:511-522.

Randle, W.M. 1992. Onion germplasm interacts with sulfur fertility for plant sulfur utilization and bulb pungency. Euphytica 59:151-156.

Randle, W.M. 2000. Increasing nitrogen concentration in hydroponic solutions affects onion flavor and bulb quality. J. Amer. Soc. Hort. Sci. 125:254-259.

Randle, W.M. and M.L. Bussard. 1993. Pungency and sugars of shortday onions as affected by sulfur nutrition. J. Amer. Soc. Hort. Sci. 118:766-770.

Randle, W.M. and Lancaster, J.E. 2002. Sulphur compounds in alliums in relation to flavour quality, p. 329-356. In H.D. Rabinowitch and L. Currah (eds.). Allium crop sciences: Recent advances. CAB Intl., Wallingford, U.K.
Randle, W.M., E. Block., M. Littlejohn, D. Putman, and M.L. Bussard. 1994. Onion (Allium cepa L.) thiosulfinates respond to increasing sulfur fertility. J. Agr. Food Chem. 42:2085-2088.

Randle, W.M., J.E. Lancaster, M.L. Shaw, K.H. Sutton, R.L. Hay, and M.L. Bussard. 1995. Quantifying onion flavor compounds responding to sulfur fertility: Sulfur increases levels of alk(en)yl cysteine sulfoxides and biosynthetic intermediates. J. Amer. Soc. Hort. Sci. 120:1075-1081.

Randle, W.M., D.E. Kopsell, D.A. Kopsell, and R.L. Snyder. 1999. Total sulfur and sulfate accumulation in onion is affected by sulfur fertility. J. Plant Nutr. 22:45-51.

Schwimmer, S. 1969. Characterization of $S$-propenyl-L-cysteine sulfoxide as the principal endogenous substrates of L-cysteine sulfoxide lyase of onion. Arch. Biochem. Biophysiology 130:312-320.

Stuiver, C.E.E., L.J. DeKok, and S. Westerman. 1997. Sulfur deficiency in Brassica oleracea L.: development, biochemical characterization, and sulfur/nitrogen interactions. Russian J. Plant. Physiol. 44:581-590.

Takahashi, S., W.C Yip, T. Matsugami, and G. Tamura. 1996. Effect of sulfur and nitrogen nutrition on derepression of ferredoxin-sulfite reductase in leek seedlings. J. Plant Res. 109:363-368. 